\title{
C.
}

\section{Amphibians of the Melghat, Maharashtra, India}

\section{Hayat A. Qureshi and Gajanan A. Wagh}

Biodiversity Research Laboratory, Department of Zoology, Shri Shivaji Science College, Amravati, Maharashtra-444603, India (gajuwagh252424@rediffmail.com)

\section{Photographs by the authors.}

$\Delta$ mphibians play important roles in the food chains of both terrestrial and aquatic ecosystem (Bahangana 2004) and are widely considered to be useful indicators of ecosystem stress (e.g., Welsh and Ollivier 1998; Sheridan and Olson 2003). Furthermore, information on amphibian diversity is becoming increasingly important in the context of global amphibian declines (e.g., Kiesecker 2010).

Of the more than 8,000 currently recognized species of amphibians (Frost 2020), 413 occur in India (Khandekar et al. 2020) and 53 have been reported from Maharashtra

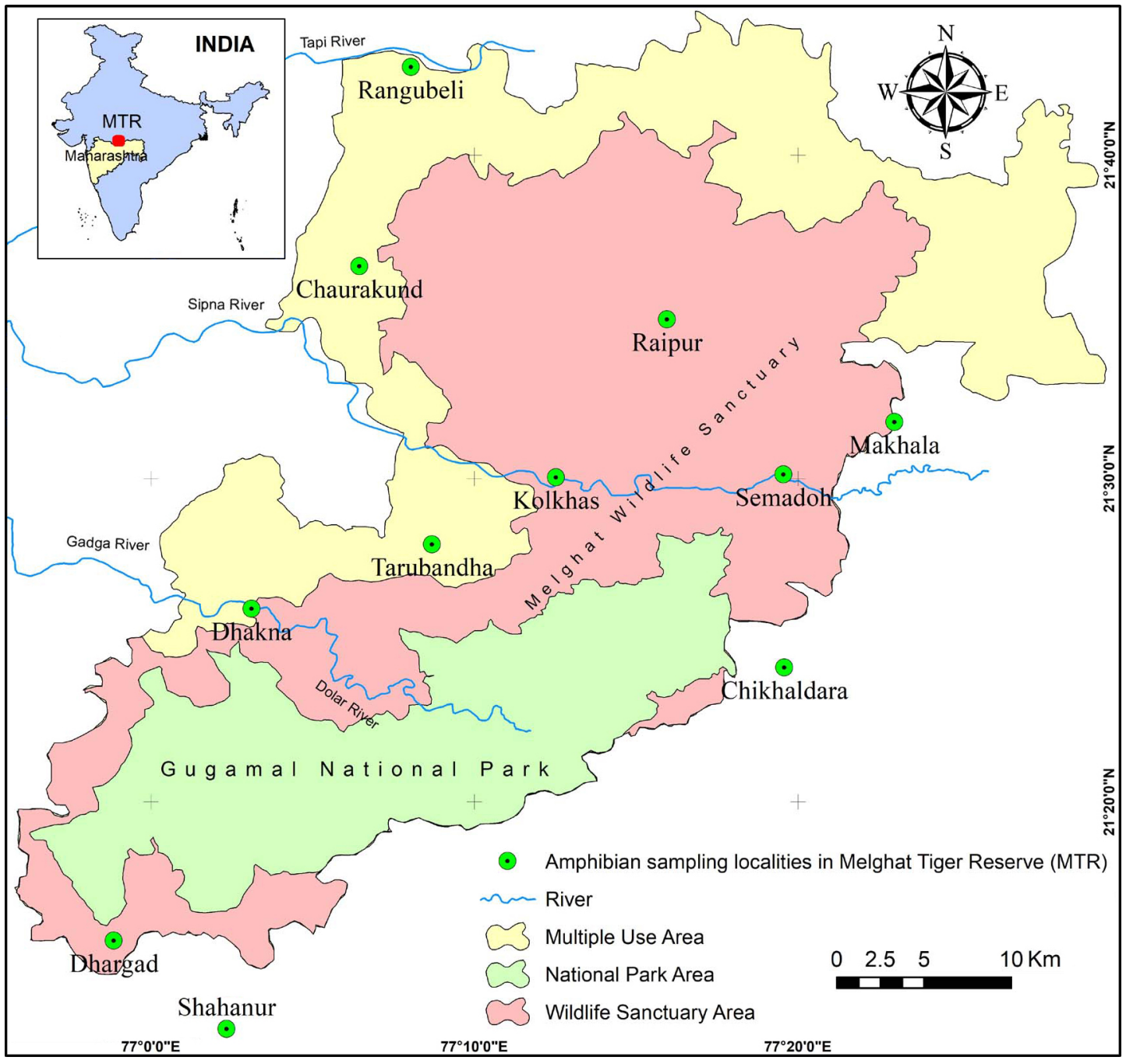

Fig. 1. Map showing sampling localities in the Melghat Tiger Reserve in the Amravati and Akola Districts of Maharashtra, India. 
Table 1. Anuran species in the Melghat Region, Maharashtra, India. Habitats: $\mathrm{Cl}=$ cultivated area, Fo $=$ forest, $\mathrm{Sp}=$ seasonal pond, $\mathrm{Ri}=$ riparian area. Status (based on frequencies of encounters): $\mathrm{C}=$ common, $\mathrm{U}=$ uncommon, $\mathrm{O}=$ occasional, $\mathrm{R}=$ rare. Red List status: $\mathrm{LC}=$ Least concern. Localities (see also Fig. 1): I = Chikhaldara, II = Semadoh, III = Kolkhas, IV = Raipur, V = Makhala, VI = Chourakund, VII

= Rangubeli, VIII = Tarubandha, IX = Dhakana, X = Dhargad, XI = Shahanur (Narnala).

Red List Locations

$\begin{array}{llllllllllllllll}\text { Family/Species } & \text { Habitat } & \text { Status } & \text { Status } & \text { I } & \text { II } & \text { III } & \text { IV } & \text { V } & \text { VI } & \text { VII } & \text { VIII } & \text { IX } & \text { X } & \text { XI }\end{array}$

\section{Bufonidae}

Common Asian Toad

\begin{tabular}{lllllllllllllllllll}
\hline Duttaphrynus melanostictus & $\mathrm{Cl}, \mathrm{Fo}$ & $\mathrm{C}$ & $\mathrm{LC}$ & + & + & + & + & + & + & + & + & + & + & +
\end{tabular}

Marbled Toad

$\begin{array}{llllllllllllll}\text { Duttaphrynus stomaticus } & \mathrm{Cl}, \mathrm{Fo} & \mathrm{C} & \mathrm{LC} & - & + & + & - & + & + & + & + & - & +\end{array}$

Rough Dwarf Toad

Duttaphrynus scaber

Fo,Ri O LC

\section{Dicroglossidae}

Skittering Frog

Euphlyctis cyanophlyctis $\quad \mathrm{Ri}, \mathrm{Sp} \quad \mathrm{C} \quad \mathrm{LC}$

Indian Cricket Frog

Fejervarya limnocharis

$\mathrm{Cl}, \mathrm{Fo}, \mathrm{Sp} \quad \mathrm{C} \quad \mathrm{LC}$

Syhadra Frog

Minervarya syhadrensis $\quad$ Fo,Ri,Sp $\quad$ R $\quad$ LC

Kerala Warty Frog

Minervarya keralensis

Fo,Sp O LC

Reddish Burrowing Frog

Minervarya rufescens

Indian Burrowing Frog

Sphaerotheca breviceps $\quad \mathrm{Cl}, \mathrm{Fo}, \mathrm{Sp} \quad \mathrm{C} \quad \mathrm{LC}$

Roland's Burrowing Frog

Sphaerotheca rolandae $\quad \mathrm{Cl}, \mathrm{Fo}, \mathrm{Sp} \quad \mathrm{R} \quad \mathrm{LC}$

Dobson's Burrowing Frog

\begin{tabular}{llll}
\hline Sphaerotheca dobsonii & $\mathrm{Cl}, \mathrm{Fo}, \mathrm{Sp}$ & $\mathrm{R}$ & $\mathrm{LC}$
\end{tabular}

Indian Bullfrog

Hoplobatrachus tigerinus $\quad \mathrm{Cl}, \mathrm{Fo}, \mathrm{Sp}, \mathrm{Ri} \quad \mathrm{C} \quad \mathrm{LC}$

Jerdon's Bullfrog

Hoplobatrachus crassus

Fo U LC

\section{Microhylidae}

Ornate Narrow-mouthed Frog

\begin{tabular}{llll}
\hline Microhyla ornata & $\mathrm{Cl}, \mathrm{Fo}, \mathrm{Sp}$ & $\mathrm{C}$ & $\mathrm{LC}$
\end{tabular}

Painted Balloon Frog

Kaloula taprobanica

Fo,Sp U LC

\section{Rhacophoridae}

Common Indian Treefrog

Polypedates maculatus

$\mathrm{Cl}, \mathrm{Fo}, \mathrm{Sp} \quad \mathrm{C} \quad \mathrm{LC}$

LC

$+\quad-\quad-$


(Padhye and Ghate 2012). In Maharashtra, considerably more attention has been devoted to amphibians in the western parts of the state than to those in the Amravati District of the Vidarbha Region. Despite the fact that the Melghat Forest receives considerable rainfall and has consistently high humidity and low temperatures, providing ideal conditions for amphibian diversity, only two previous studies (Kamble 2005; Wagh et al. 2017) have addressed the amphibians of the Melghat Region. Herein we provide a comprehensive updated checklist of anurans from the that region.

The Melghat Area of the Amravati District consists of a succession of hills and valleys, which are extensions of the main Satpuda Range. The crests of this range attain an average elevation of about $1,000 \mathrm{~m}$ asl, with the highest peak $(1,178$ $\mathrm{m})$ at Vairat near Chikaladara. The climate is tropical, with winter temperatures of $13-22{ }^{\circ} \mathrm{C}$ and summer temperatures of $23-46{ }^{\circ} \mathrm{C}$. Annual rainfall ranges from $1,000 \mathrm{~mm}$ to 2,250 $\mathrm{mm}$. Vegetation is Southern Tropical Dry Deciduous Forest (Champian and Seth 1968 ) and the Sipna, Khapra, Khandu, Dolar, Gadga, and Chopan are the major rivers. They and many seasonal rivulets are tributaries of the westward-flowing
Tapi River. The 3,970- $\mathrm{km}^{2}$ Melghat Tiger Reserve (MTR) is in the Melghat Forest $\left(20^{\circ} 51^{\prime}-21^{\circ} 46^{\prime} \mathrm{N}, 76^{\circ} 38^{\prime}-77^{\circ} 33^{\prime} \mathrm{E}\right)$ of the Amravati and Akola Districts of Maharashtra (Fig. 1).

We conducted extensive rainy-season belt-transect surveys in the morning (0530-0830 h) and at night (1900-2200 h) at seven-day intervals from June 2016 to October 2018 in all available habitats (open land, streams, rivers, seasonal ponds, dense forest, and grasslands) at eleven localities in the MTR (Chikhaldara, Semadoh, Kolkhas, Raipur, Makhala, Chourakund, Rangubeli, Tarubandha, Dhakana, Dhargad, and Shahanur [Narnala]; Fig. 1). We did not collect any specimens but photographed all possible individuals. We confirmed the identities of frogs using various diagnostic keys and descriptions in Das and Dutta (1998), Chanda (2002), Daniel (2002), Daniels (2005), Gururaja (2012), and Dinesh et al. (2015), in some instances with additional assistance from amphibian experts at the Zoological Survey of India.

We documented the presence of 16 anuran species in four families and nine genera (Table 1; Figs. 2-4). Not surprisingly, the most frequently encountered species (Duttaphrynus melanostictus, Duttaphrynus stomaticus, Euphlyctis cyanophlyctis,
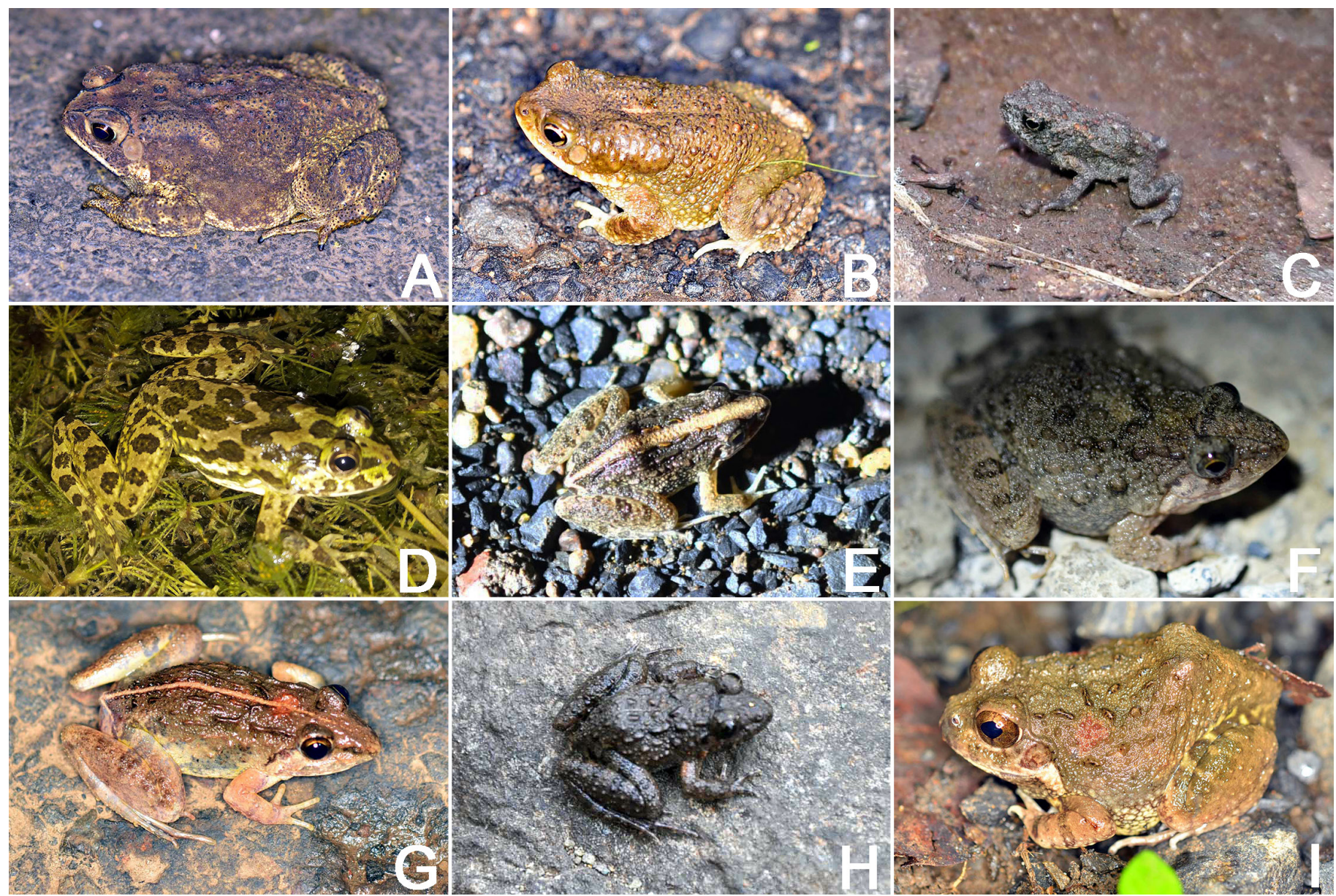

Fig. 2. Anuran species recorded from the Melghat Tiger Reserve, Maharashtra, India: (A) Common Asian Toad (Duttaphrynus melanostictus), (B) Marbled Toad (Duttaphrynus stomaticus), (C) Ferguson's Toad (Duttaphrynus scaber), (D) Skittering Frog (Euphlyctis cyanophlyctis), (E) Indian Cricket Frog (Fejervarya limnocharis), (F) Syhadra Frog (Minervarya syhadrensis), (G) Kerala Warty Frog (Minervarya keralensis), (H) Reddish Burrowing Frog (Minervarya rufescens), (I) Indian Burrowing Frog (Sphaerotheca breviceps). 

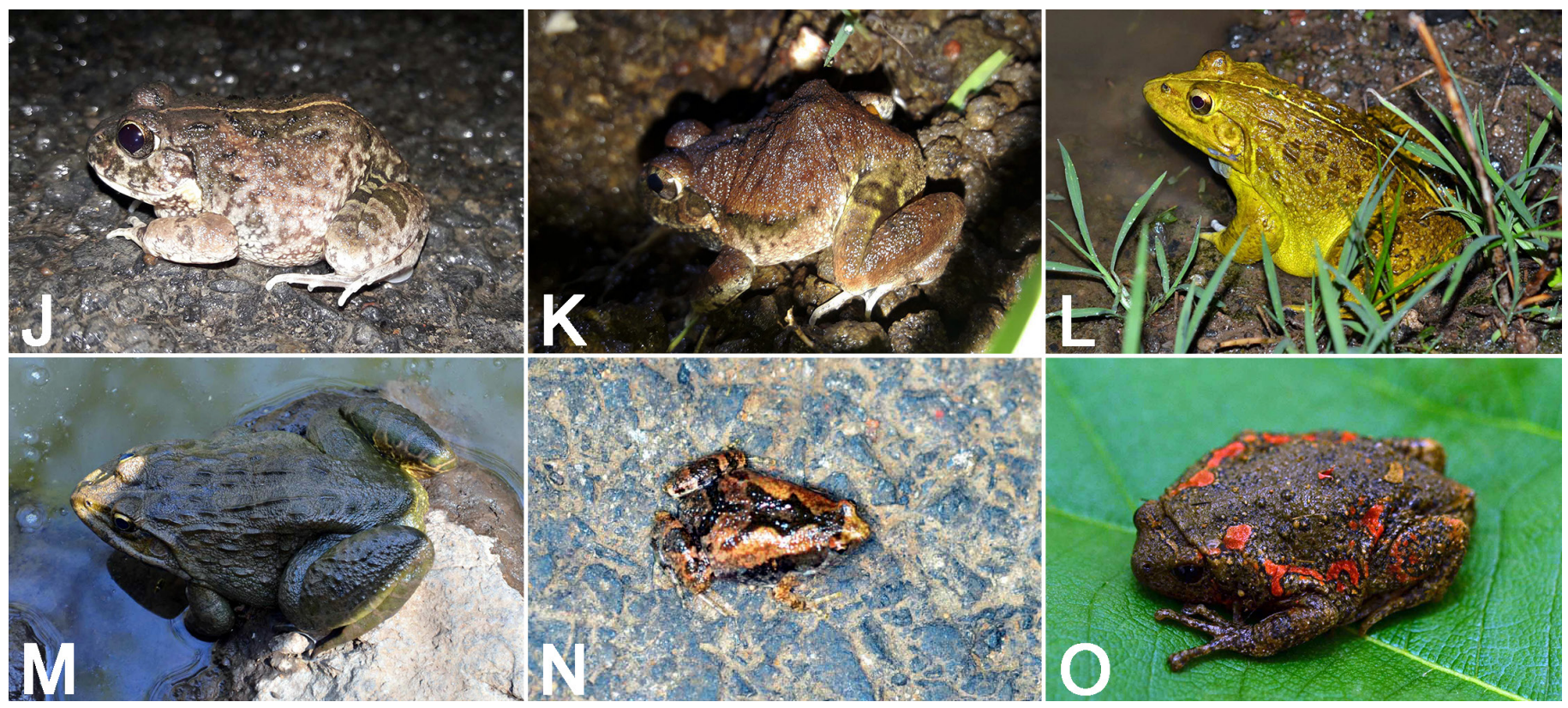

Fig. 3. Anuran species recorded from the Melghat Tiger Reserve, Maharashtra, India: (J) Roland's Burrowing Frog (Sphaerotheca rolandae), (K) Dobson's Burrowing Frog (Sphaerotheca dobsonii), (L) Indian Bullfrog (Hoplobatrachus tigerinus), (M) Jerdon's Bullfrog (Hoplobatrachus crassus), (N) Ornate Narrowmouthed Frog (Microhyla ornata), (O) Painted Balloon Frog (Kaloula taprobanica).

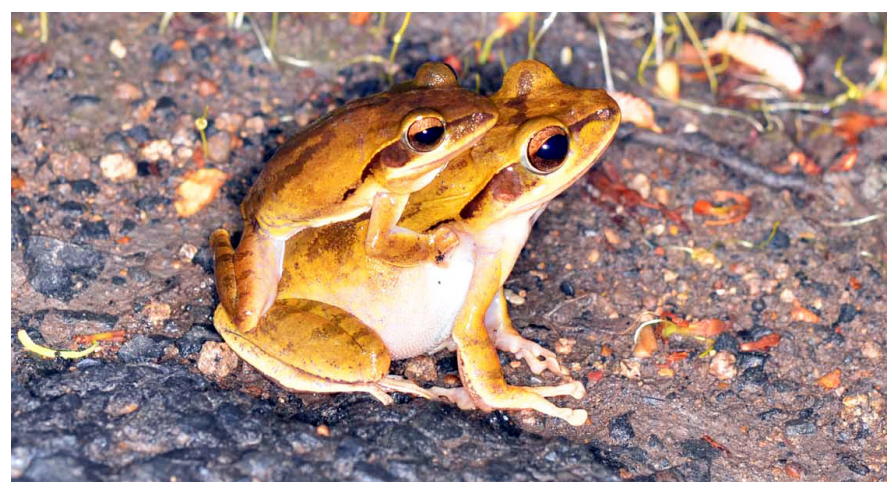

Fig. 4. Anuran species recorded from the Melghat Tiger Reserve, Maharashtra, India: Common Indian Treefrog (Polypedates maculatus).

Fejervarya limnocharis, Sphaerotheca breviceps, Hoplobatrachus tigerinus, Microhyla ornata, and Polypedates maculatus) generally were found at the most localities and usually in the greatest diversity of habitats. However, three rarely encountered species (Minervarya syhadrensis, Sphaerotheca rolandae, and Sphaerotheca dobsonii) were found in three of the four sampled habitat types.

Our results compare favorably with those of previous surveys. In his list of amphibians from the MTR, Kamble (2005) recorded eight species that correspond to those we most frequently encountered. Wagh et al. (2017) recorded 11 species from various habitats in the Amravati District, essentially those documented by Kamble (2005) plus two species we found to be uncommon (Holobatrachus crassus and Kaloula taprobanica) plus an unidentified species of Fejervarya (undoubtedly one of the species subsequently assigned to the genus Minervarya).
Although all of the anuran species we encountered in the Melghat Region are included on the IUCN Red List as being of least concern, local populations could be declining as a consequence of habitat destruction, alteration, and fragmentation, road kills, and the increasingly extensive use of pesticides and herbicides by local farmers in the Melghat.

\section{Acknowledgements}

We thank the Chief Conservator of Forest and Field Director of the Melghat Tiger Reserve (MTR) for granting permission to carry out this study, and the officers and staff for their support during the study period. We also thank Dr. Satish Kamble of the Zoological Survey of India for helping with the identification of some species. Mr. Shubham Wagh designed the map of the study area (Fig. 1). Saddam Khan, Jagdev Iwane, and Pratmesh Tiwari helped with field surveys.

\section{Literature Cited}

Behangana, M. 2004. The diversity and status of amphibians and reptiles in the Kyoga Lake Basin. African Journal of Ecology 42: 52-56.

Champion, H.G. and S.K. Seth. 1968. A Revised Survey of the Forest Types of India. Government of India Press, New Delhi, India.

Chanda, S.K. 2002. Handbook - Indian Amphibians. Zoological Survey of India, Calcutta, India.

Daniel, J.C. 2002. The Book of Indian Reptiles and Amphibians. Bombay Natural History Society and Oxford University Press, Mumbai, India.

Daniels, R.J.R. 2005. Amphibians of Peninsular India. Universities Press (India) Private Limited, Hyderabad, India.

Das, I. and S.K. Dutta. 1998. Checklist of amphibians of India with English and common names. Hamadryad 23: 63-68.

Dinesh, K.P., C. Radhakrishnan, B.H. Channakeshavamurthy, P. Deepak, and N.U. Kulkarni. 2017. A Checklist of Amphibian of India (Updated till April 2017). Mhadei Research Center, Belgaum, Karnataka, India. <https://mhadeiresearchcenter.org/wp-content/uploads/2014/01/2017_April_Checklist- 
of-Amphibians-of-India.pdf>.

Frost, D.R .2020. Amphibian Species of the World: An Online Reference. Version 6.1. American Museum of Natural History, New York, New York. <https:// amphibiansoftheworld.amnh.org>.

Gururaja, K.V. 2012. Pictorial Guide to Frogs and Toads of the Western Ghats. Gubbi Labs LLP, Gubbi, Karnataka, India.

Kamble, S.S. 2005. Amphibians, pp. 223-230. In: A. Mahabal (Project Co-ordinator), Fauna of Melghat Tiger Reserve, Conservation Area Series 24. Zoological Survey of India, Kolkata, India.

Khandekar, A., N. Gosavi, P. Roy, and K. Kunte (eds.). 2020. Amphibians of India, V.1.05. Indian Foundation for Butterflies and the National Centre for Biological Sciences (NCBS), Bangalore, Karnataka, India. <https://www. indianamphibians.org/homes.
Kiesecker, M.J. 2010. Global stressors and global decline of amphibians: tipping the stress immunocompetency axis. Ecological Research 26: 897-908.

Padhye, A.D. and H.V. Ghate. 2012. Amphibia. Zoological Survey of India. Fauna of Maharashtra, State Fauna Series 20 (part 1): 239-246.

Sheridan, C.D. and D.H. Olson. 2003. Amphibian assemblage in zero-order basins in the Oregon Coast Range. Canadian Journal of Forest Research 33: 1452 1477.

Wagh, G.A., A.S. Rawankar, V. Sharma, and J.S. Wadatkar. 2017. A preliminary study on the amphibian diversity in different habitats of Amravati District, Maharashtra. Journal of Entomology and Zoological Studies 5: 158-162.

Welsh, H.H., Jr. and L.M. Ollivier. 1998. Stream amphibians as indicators of ecosystem stress: A case study from California redwoods. Ecological Applications 8: $1118-1132$. 